\title{
Intramedullary nail with integrated cephalocervical screws in the intertrochanteric fractures treatment: Position of screws in fracture stability
}

\author{
Gökhan Kaynak, M.D., Mehmet Can Ünlü, M.D., Mehmet Fatih Güven, M.D., Ozan Ali Erdal, M.D., \\ Okan Tok, M.D., Hüseyin Botanlıoğlu, M.D., Önder Aydıngöz, M.D.
}

Department of Orthopedics and Traumatology, İstanbul University Cerrahpasa Faculty of Medicine, İstanbul-Turkey

\begin{abstract}
BACKGROUND: Stable fracture fixation is important in the treatment of intertrochanteric femur (ITF) fractures in the elderly population to prevent the loss of reduction, achieve early mobility, and restore independence. The aim of this study was to present the results of surgical treatment of stable and unstable ITF fractures using a trochanteric antegrade intramedullary nail with two cephalocervical screws in an integrated mechanism (Intertan ${ }^{\circledR}$; Smith \& Nephew, Memphis, TN) and evaluate the relationship between the loss of reduction and screw position in the femoral neck in two planes.
\end{abstract}

METHODS: The authors investigated all varus misalignments and losses of reduction in 57 patients (22 males, 35 females) treated for ITF fractures with the Intertan ${ }^{\circledR}$ between 2010 and $201 \mathrm{I}$. Two indices (screw alignment index in the frontal projection [SAlcoronal] and screw alignment index in the lateral projection [SAlsagittal]) were defined to evaluate the loss of reduction. Patients were also evaluated according to the Harris hip score and Barthel independence index.

RESULTS: The mean patient age was 77.I years. The mean follow-up period was 21.7 months. All patients achieved complete union. We did not detect any varus collapse or loss of reduction. At the end of the follow-up period, the mean Barthel independence index was 90.7, and the mean Harris hip score was 83.7.

CONCLUSION: The use of a trochanteric antegrade intramedullary nail with two cephalocervical screws allows for linear intraoperative compression and rotational stability of the head/neck fragment, prevents reduction loss, and has a wide application area in the femoral head. Its inherent continuous stability permits early weight-bearing and mobilization. It is a safe and an efficient option for the treatment of ITF fractures.

Keywords: Hip fractures; integrated cephalocervical screws; intertrochanteric fractures; outcome; screw position.

\section{INTRODUCTION}

Intertrochanteric femur (ITF) fractures are among the most common orthopedic injuries in the elderly population and are mainly treated surgically. ${ }^{[1,2]}$ The surgical treatment of ITF fractures aims to achieve early ambulation and to restore the patient's walking capacity to the pre-injury level. Intramedullary (IM) nail-screw devices offer distinct biomechanical advantages over other types of fixation devices. IM nails are load-sharing devices, offer three-point fixation, and are located more closely to the axis of weight-bearing. ${ }^{[3]}$ The main problem with these devices is varus collapse due to loss of reduction.

There are a few studies on the trochanteric antegrade IM nails that use two cephalocervical screws in an integrated mechanism, allowing for linear intraoperative compression and rotational stability of the head/neck fragment. ${ }^{[4,5]}$

The aim of this study was to present the results of the treatment of stable and unstable ITF fractures using a trochanteric

Cite this article as: Kaynak G, Ünlü MC, Güven MF, Erdal OA, Tok O, Botanlığlu H, et al. Intramedullary nail with integrated cephalocervical screws in the intertrochanteric fractures treatment: Position of screws in fracture stability. Ulus Travma Acil Cerrahi Derg 2018;24:268-273.

Address for correspondence: Mehmet Can Ünlü, M.D.

İstanbul Üniversitesi Cerrahpaşa Tıp Fakültesi, Ortopedi ve Travmatoloji Anabilim Dalı, İstanbul, Turkey

Tel: +90 212 - 4l43000 E-mail: unludilek@hotmail.com

Ulus Travma Acil Cerrahi Derg 2018;24(3):268-273 DOI: 10.5505/tjtes.2017.96933 Submitted: 08.08.2017 Accepted: 22.09.2017 Online: 09.1I.2018

Copyright 2018 Turkish Association of Trauma and Emergency Surgery 
antegrade IM nail with two cephalocervical screws in an integrated mechanism (Intertan ${ }^{\circledR}$; Smith \& Nephew, Memphis, TN) and evaluate the relationship between the loss of reduction and placement of the screws in the femoral neck in both the coronal and sagittal planes.

\section{MATERIALS AND METHODS}

Our Institutional Review Board approved the chart review for this study, and informed consent was obtained from all patients. From February 2010 to June 201 I, a total of 71 patients with ITF fractures underwent operations at our institution. We retrospectively reviewed the medical records of all patients. Patients with ITF fractures who underwent closed reduction and internal fixation with IM nails and integrated cephalocervical screws (Intertan ${ }^{\circledR}$ nail; Smith \& Nephew, Memphis, TN) were included in the study. Exclusion criteria were the pathological fractures, inadequate radiographs, incomplete data, and loss to follow-up.

In total, 57 patients (22 males and 35 females) matched these criteria. The mean age of the patients at the time of surgery was 77.I years (range, 58-98 years,) and the mean follow-up time was 21.7 months (range, 13-30 months). All fractures were classified according to the AO/OTA classification system ${ }^{[6]}$ using preoperative radiographs; 18 of the patients were had stable fractures, whereas the remaining 39 had unstable fractures.

Surgical procedures were performed by an orthopedic surgeon of either registrar grade (unsupervised) or consultant grade (all are authors of this manuscript).

All patients gave written informed consent before any studyrelated procedure was conducted. The study was carried out in accordance with the latest version of the Declaration of Helsinki, and the study protocol was approved by the local ethics committee.

\section{Surgical Technique}

General or regional anesthesia was used for all patients. All patients were placed on a radiolucent fracture table in the supine position and I $g$ of cefazolin sodium was administered for surgical prophylaxis. After the satisfactory completion of closed reduction was verified by fluoroscopy (Fig. I), standard skin preparation and sterilization was performed. A 5 to $7-\mathrm{cm}$ longitudinal incision was used proximal to the tip of the greater trochanter. A threaded-tip guide wire was placed on the tip of the trochanter under fluoroscopic control and driven into the bone for up to $5 \mathrm{~cm}$. The entry point was then drilled with a cannulated 16-mm double drill. Once the appropriate size and neck angle of the implant was determined, the nail was inserted into the shaft so that the entry point of the lag screw would be placed into the head/neck of the femur in the fluoroscopic anteroposterior view. The insertional sleeves were placed into the screw guide, and a guide wire was drilled into the proximal fragment for the proximal lag screw. The guide wire was advanced to the subchondral portion of the femoral head. The lag screw guide wire was measured, and a one-size-shorter screw was selected. The lag screw was then advanced, bringing its tip as close to the subchondral bone as possible. During the insertion of the lag screw, an antirotation blade was used to prevent the rotation of the proximal fragment. After the insertion of the lag screw, a compression screw was applied to achieve compression at the fracture site. When the interlocking screws were in appropriate places, the preassembled set screw was firmly tightened to prevent pullout. A distal locking screw was then statically inserted into the nail through the screw guide via a stab wound incision of I-2 $\mathrm{cm}$ in length, and the wounds were then closed.

\section{Postoperative Rehabilitation}

Full weight-bearing was allowed on the first postoperative day as tolerated by the patient. Vigorous mobilization, rangeof-motion exercises, and respiratory physiotherapy were initiated immediately.

\section{Postoperative Follow-up}

Full weight-bearing without pain and callus formation on both anteroposterior and lateral radiographs of the affected hip were the criteria for fracture union.

Patients were evaluated clinically using the Harris hip score ${ }^{[7]}$ and Barthel independence index ${ }^{[8]}$ at the final follow-up.

The Harris hip score rates the patient's complaints and functional status based on a severity-symptom scale and functional status. This scale contains four question categories (pain, function, functional activities, and physical exam results). The total score ranges from 0 to 100 points; a score of 100 is considered the best. A score of $90-100$ is considered excellent, $80-89$ is considered good, $70-79$ is considered fair, and $<70$ is considered poor.

The Barthel independence index comprises 10 items that measure a person's daily functioning, specifically the activities of daily living and mobility. The total score ranges from 0 to
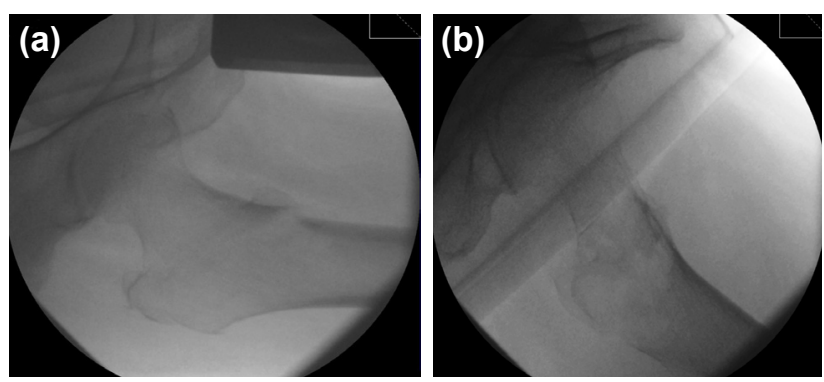

Figure 1. Anteroposterior (a) and lateral (b) fluoroscopic views showing closed reduction of the right hip of a 77-year-old female. The criteria for satisfactory closed reduction were continuity of tensile and compressive force lines, continuity of the cortex in the coronal and sagittal planes, and adequate anteversion in the sagittal plane. 
100 points; a score of 100 is considered best. The higher the score, the more "independent" the person. Independence means that the person needs no assistance with any part of the task. If a person performs approximately $50 \%$ of the task independently, then the middle score would apply.

Plain anteroposterior and lateral radiographs of the affected hip taken on the day of surgery and at the last follow-up were used for radiographic measurements. All radiographic measurements were performed uniformly by the same orthopedic surgeon (author of this manuscript).

\section{Measuring the Screw Alignment in the Coronal Plane}

The outer sides of the superior and inferior cortices of the femoral neck at its narrowest points were marked on the anteroposterior view. The distances from each point perpendicular to the midline of the compression and lag screw combination were measured. The lateral measurement was the " $x$ " value, medial measurement was the " $y$ " value, and the " $x+$ $y$ " value was calculated. We reproduced the screw alignment index in the coronal plane (SAlcoronal) by calculating $y /(x+$ y) $\times 100$ (Fig. 2a). In this way, we could determine the location of the screw placement in the coronal plane. A ratio of 0 to 33 was accepted as inferior placement, 34 to 66 as central placement, and 67 to 100 as superior placement of the screws.

\section{Measuring the Screw Alignment in the Sagittal Plane}

We drew a line tangential to the proximal tip of the nail and
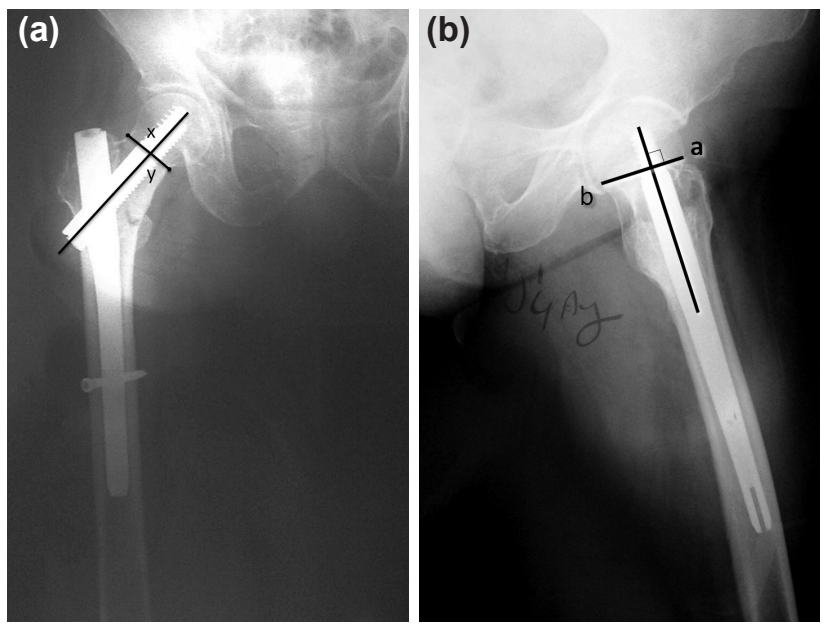

Figure 2. Screw alignment index (a) (measurement of screw location) was defined as the absolute distance of the screws from the medial cortex (y) or posterior cortex (b) at the narrowest point of the femoral neck as measured on an anteroposterior or lateral radiograph, respectively, divided by the width of the femoral neck $[(x+y)$ or $(a+b)]$ at the narrowest point of the femoral neck as measured on an anteroposterior or lateral radiograph, respectively. This number was then multiplied by 100 to yield a percentage. This percentage allowed for a magnification correction on radiographs taken at different times and with different magnifications. perpendicular to the line drawn in the middle of the axis of the lag screw. We then measured the distances from the intersection point to each cortex. The anterior measurement was "a," the posterior measurement was "b," and the "a + b" value was calculated. We reproduced the screw alignment index in the sagittal plane (SAlsagittal) by calculating $b /(a+b)$ $\times 100$ (Fig. 2b). In this way, we could determine the position of the screws in the sagittal plane. A ratio of 0 to 33 was accepted as posterior placement, 34 to 66 as central placement, and 67 to 100 as anterior placement of the screws.

\section{Measuring the Varus Angle}

The varus angle (VA) was measured on anteroposterior radiographs. A transverse line was drawn across the proximal femoral shaft, passing through the most distal part of the lesser trochanter and lateral projection of the tip of the cephalocervical screws. A line connecting the center of the femoral head and lateral projection of the tip of the cephalocervical screws was drawn. The angle between these two lines was defined as VA (Fig. 3).

\section{Measuring the Tip Apex Distance (TAD)}

Tip apex distance (TAD) II is the combined distance, measured in millimeters, from the tip of the cannulated screw to the apex of the femoral head on both anteroposterior and lateral radiographs. The magnification is standardized by measuring the diameter of the cannulated screw.

SAlcoronal and SAlsagittal measurements at the last followup were compared with those on the day of surgery to assess

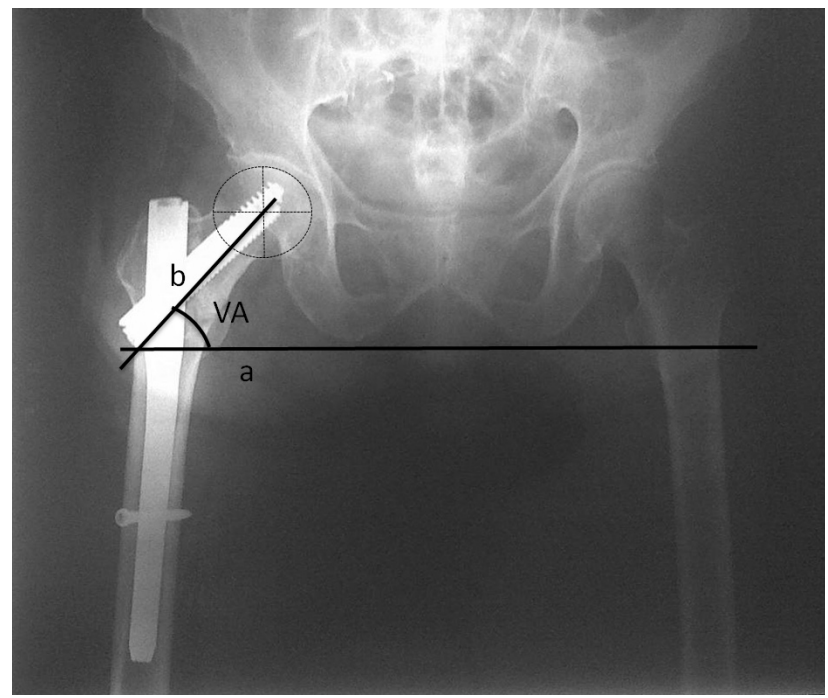

Figure 3. The varus angle was measured on anteroposterior radiographs. A transverse line was drawn across the proximal femoral shaft, passing through the most distal part of the lesser trochanter and the lateral projection of the tip of the cephalocervical screws (a). A line connecting the center of the femoral head and lateral projection of the tip of the cephalocervical screws was drawn (b). These lines were extended until they intersected, and the angle of intersection was measured. VA: Varus angle. 
any loss in reduction. VA at the last follow-up was compared with that on the day of surgery to assess any varus collapse. The TAD measurement on the day of surgery was used to assess the adequacy of implant position; a TAD of $>25 \mathrm{~mm}$ was used as a predictor of cut-out II.

Revision surgeries, additional procedures, and complications (including wound infection, deep infection, hematoma, and fractures around the implant) were documented.

\section{Statistical Analyses}

Statistical methods designed for independent observations were used. The mean value and standard deviation were calculated. Continuous variables were compared using the Student's t-test, and categorical variables were compared using the chi-square test. The level of significance was defined as $p<0.05$. Pearson's correlation analyses were applied for the relationships. All analyses were performed using the SPSS statistical software package (ver. 17.0 for Windows; SPSS, Chicago, IL, USA).

\section{RESULTS}

Closed reduction was achieved in all patients. All patients achieved union with no complications. The mean union time was 12.2 weeks (range, 10.0-16.0 weeks). The mean time interval between trauma and surgery was 8.7 days (range, 0-32 days). The mean surgery time was $25 \mathrm{~min}$ (range, 14-40 $\mathrm{min}$ ). The average hospital stay was 17.9 days (range, 7-63 days), depending on the length of the postoperative physiotherapy period, social circumstances, and length of intensive care unit stay.

There were three superficial wound infections, all of which resolved with oral antibiotics by the time the sutures were removed. No patient required revision surgery or other procedures at the final follow-up.

In the majority of the patients, the screws were located in the central position in both the coronal and sagittal planes (Table I). The differences in SAlcoronal, SAlsagittal, and VCl on the day of surgery and at the final follow-up were not significant. There was no varus collapse in any patient. The mean TAD was $22.3 \mathrm{~mm}$ (range, 8.0-39.2 $\mathrm{mm}$ ).

The mean Barthel index was 90.7 (range, 20-100), and in 43 patients $(75 \%)$, the indices were $>90$ at the last follow-up. The mean Harris hip score was 83.7 (range, 44-98). The results of 16 patients $(28 \%)$ were poor or fair, whereas $4 \mathrm{I}$ patients $(72 \%)$ were defined as either good or excellent according to the Harris hip score. The Barthel index and Harris hip scores were evaluated in terms of the presence of any statistically significant correlation between these scores and age, gender, fracture type, preoperative hospital stay, and total length of hospitalization. The only statistically sig-
Table I. Positions of the screws in the coronal and sagittal planes

\begin{tabular}{lcc}
\hline & Day of surgery & Last follow-up \\
\hline SA $_{\text {coronal }}$ & & \\
Inferior & $5(9 \%)$ & $6(10 \%)$ \\
Central & $52(91 \%)$ & $49(86 \%)$ \\
Superior & None & $2(4 \%)$ \\
SAI $_{\text {sagittal }}$ & & $6(10 \%)$ \\
Posterior & $4(7 \%)$ & $47(83 \%)$ \\
Central & $48(84 \%)$ & $4(7 \%)$ \\
Anterior & $5(9 \%)$ & \\
\hline $\begin{array}{l}\text { Values are numbers of patients with percentages in parentheses. SAl: Screw } \\
\text { alignment index. }\end{array}$ &
\end{tabular}

nificant finding was a negative correlation between age and the Harris hip score $(p=0.044)$ or Barthel index $(p=0.002)$ at the final follow-up.

\section{DISCUSSION}

In this retrospective study, we analyzed the clinical and radiological outcomes of ITF fractures treated with trochanteric antegrade nails with two cephalocervical screws in an integrated mechanism in 57 patients. ITF fractures in the elderly population are associated with considerable morbidity and mortality because of accompanying comorbidities. ${ }^{[9,10]}$

Since the first report on the use of a sliding hip screw (SHS), this device has become a standard treatment modality for ITF fractures. ${ }^{[6,1]}$ However, comminuted and unstable ITF fractures treated with SHS may result in significant malunion and femoral neck shortening. ${ }^{[3]}$ Although free of complications, early weight-bearing is unlikely with $\mathrm{SHS} .^{[3]} \mathrm{IM}$ nail-screw devices offer distinct biomechanical advantages over other types of fixation devices. IM nails are load-sharing devices, offer three-point fixation, and are located closer to the weightbearing axis. ${ }^{[3]}$ This is especially important in unstable fractures that present with medial column compromise. ${ }^{[12]}$

The most serious and often devastating complication of the first-generation IM fixation devices that have a single centrally placed lag screw to secure the femoral head and neck ${ }^{[13]}$ is the varus collapse of the femoral neck; this is also called "cut-out" and is caused by the perforation of a lag screw through the cortex. ${ }^{[14]}$ This is thought to be caused either by improper lag screw placement in the anterior-superior quadrant of the head or by not placing the screw close enough to the subchondral region of the head. However, in reality, when the patient starts walking, the lag screw becomes a pivot point and the femoral head starts rotating at this point, which results in loosening of the bone-screw interface. ${ }^{[4,14]}$ To avoid this complication, second-generation systems using 
two separate screws were developed. Unfortunately, these devices are associated with the complications such as the migration of screws in opposite directions (Z-effect and reverse Z-effect), which is caused by the disproportionate load during weight-bearing. ${ }^{[15]}$ Many previous studies advocated the central placement of the screws to prevent cut-out and promote more stable fracture fixation, ${ }^{[16,17]}$ although Kaufer ${ }^{[18]}$ advised the placement of the screws in the posteroinferior quadrant of the femoral head.

However, the application of the lag screw into a specific quadrant of the femoral head can sometimes be difficult and result in prolonged operation duration, especially in overweight patients or when the intraoperative fluoroscopic views are not clear enough.

The limitations and complications of both first- and secondgeneration systems have led to the development of a thirdgeneration system consisting of an IM nail with integrated cephalocervical screws.

The Intertan ${ }^{\circledR}$ device (Smith \& Nephew, Memphis, TN) with integrated cephalocervical screws is a reliable device that permits compression at the fracture site.

The compression screw prevents rotation by interlocking into the lag screw. The Z-effect can be prevented by the proximal preassembled set screw that locks the interlocking screws. Ruecker et al. ${ }^{[4]}$ and Qin also reported that the In$\operatorname{tertan}^{\circledR}$ device appears to be a reliable implant for the treatment of ITF femoral fractures and to have low complication rates with a shorter recovery period from the pre-injury level. ${ }^{[5]}$

Femoral neck shortening because of uncontrolled ITF fracture collapse is another complication of both IM nails and SHS constructs, causing limb length discrepancy and maladaptation of the abductor lever arm. ${ }^{[19]}$ Although some compression is needed for fracture healing, uncontrolled fracture collapse can cause migration of the screw, which results in pain and shortening. Satisfactory functional outcomes with near-normal gait restoration can be achieved in cases of ITF hip fractures with an emphasis on calcar reduction and compression. ${ }^{[20]}$ We believe that devices allowing controlled compression at the fracture site help surgeons to reconstruct the medial column and prevent further collapse. Our findings indicate that the central or inferior placement of the lag screws in the coronal plane and in any of the three quadrants in the sagittal plane is sufficient for stable fracture fixation as long as good reduction and compression of the fracture site is achieved with a secure implant.

Although Norris reported that proximal femoral IM nails have been associated with a risk of late fracture around the implant, ${ }^{[2]}$ we experienced no implant-related femoral fractures in our series. Matre 22 reported five postoperative peri-implant femoral fractures in patients treated with the Intertan ${ }^{\circledR}$ device for ITF fractures within the first 3 months. Such complications may occur with increased follow-up durations.

There were a few limitations to this study. First, our findings were limited to the specific implant used in this study. Although its design is not dissimilar to many other currently available anatomic implants, our findings may not be generalizable to all other IM nails with integrated cephalocervical screws. Second, this study was performed without randomization. Third, we did not obtain repeatability or intraobserver variability data for the radiological measurements.

In the surgical treatment of ITF fractures, the application of the lag screw into a specific quadrant of the femoral head can sometimes be difficult and result in prolonged operation durations and additional intraoperative fluoroscopic imaging, causing more radiation exposure. Multiple drillings of the osteoporotic bone to locate the lag screw placement site may lower the quality of the bone stock for adequate fixation stability.

\section{Conclusion}

Trochanteric antegrade nails that involve the use of two cephalocervical screws in an integrated mechanism allow for linear intraoperative compression and rotational stability of the head/neck fragment, prevent reduction loss, have a wide range of application areas in the femoral head, and are a good option for the treatment of ITF fractures in the elderly population.

\section{Conflict of interest: None declared.}

\section{REFERENCES}

1. Chan KC, Gill GS. Cemented hemiarthroplasties for elderly patients with intertrochanteric fractures. Clin Orthop Relat Res 2000;(371):206-15.

2. Zhou F, Zhang ZS, Yang H, Tian Y, Ji HQ, Guo Y, et al. Less invasive stabilization system (LISS) versus proximal femoral nail anti-rotation (PFNA) in treating proximal femoral fractures: a prospective randomized study. J Orthop Trauma 2012;26:155-62. [CrossRef]

3. Bienkowski P, Reindl R, Berry GK, Iakoub E, Harvey EJ. A new intramedullary nail device for the treatment of intertrochanteric hip fractures: Perioperative experience. J Trauma 2006;61:1458-62. [CrossRef]

4. Ruecker AH, Rupprecht M, Gruber M, Gebauer M, Barvencik F, Briem $\mathrm{D}$, et al. The treatment of intertrochanteric fractures: results using an intramedullary nail with integrated cephalocervical screws and linear compression. J Orthop Trauma 2009;23:22-30. [CrossRef]

5. Qin H, An Z. Therapeutic evaluation of femoral intertrochanteric fractures by InterTan. Zhongguo Xiu Fu Chong Jian Wai Ke Za Zhi 2010;24:1424-7.

6. Müller ME, Nazarian S. Classification of fractures of the femur and its use in the A.O. index. Rev Chir Orthop Reparatrice Appar Mot 1981;67:297-309. [CrossRef]

7. Harris WH. Traumatic arthritis of the hip after dislocation and acetabular fractures: treatment by mold arthroplasty. An end-result study using a 
new method of result evaluation. J Bone Joint Surg Am 1969;51:737-55.

8. Wade DT, Collin C. The Barthel ADL Index: a standard measure of physical disability? Int Disabil Stud 1988;10:64-7. [CrossRef]

9. Kesmezacar H, Ayhan E, Unlu MC, Seker A, Karaca S. Predictors of mortality in elderly patients with an intertrochanteric or a femoral neck fracture. J Trauma 2010;68:153-8. [CrossRef]

10. Richmond J, Aharonoff GB, Zuckerman JD, Koval KJ. Mortality risk after hip fracture. J Orthop Trauma 2003;17:53-6. [CrossRef]

11. Rupprecht M, Grossterlinden L, Ruecker AH, de Oliveira AN, Sellenschloh K, Nüchtern J, et al. A comparative biomechanical analysis of fixation devices for unstable femoral neck fractures: the Intertan versus cannulated screws or a dynamic hip screw. J Trauma 2011;71:625-34.

12. Mahomed N, Harrington I, Kellam J, Maistrelli G, Hearn T, Vroemen J. Biomechanical analysis of the Gamma nail and sliding hip screw. Clin Orthop Relat Res 1994:280-8. [CrossRef]

13. Williams WW, Parker BC. Complications associated with the use of the gamma nail. Injury 1992;23:291-2. [CrossRef]

14. Kawatani Y, Nishida K, Anraku Y, Kunitake K, Tsutsumi Y. Clinical results of trochanteric fractures treated with the TARGON ${ }^{\curvearrowleft}$ proximal femur intramedullary nailing fixation system. Injury 2011;42 Suppl 4:S22-7.

15. Pervez H, Parker MJ, Vowler S. Prediction of fixation failure after sliding hip screw fixation. Injury 2004;35:994-8. [CrossRef]
16. Baumgaertner MR, Curtin SL, Lindskog DM, Keggi JM. The value of the tip-apex distance in predicting failure of fixation of peritrochanteric fractures of the hip. J Bone Joint Surg Am 1995;77:1058-64. [CrossRef]

17. Pires RE, Santana EO Jr, Santos LE, Giordano V, Balbachevsky D, Dos Reis FB. Failure of fixation of trochanteric femur fractures: Clinical recommendations for avoiding $Z$-effect and reverse $Z$-effect type complications. Patient Saf Surg 2011;5:17. [CrossRef]

18. Kaufer H. Mechanics of the treatment of hip injuries. Clin Orthop Relat Res 1980:53-61. [CrossRef]

19. Paul O, Barker JU, Lane JM, Helfet DL, Lorich DG. Functional and radiographic outcomes of intertrochanteric hip fractures treated with calcar reduction, compression, and trochanteric entry nailing. J Orthop Trauma 2012;26:148-54. [CrossRef]

20. Han N, Sun GX, Li ZC, Li GF, Lu QY, Han QH, et al. Comparison of proximal femoral nail antirotation blade and reverse less invasive stabilization system-distal femur systems in the treatment of proximal femoral fractures. Orthop Surg 2011;3:7-13. [CrossRef]

21. Norris R, Bhattacharjee D, Parker MJ. Occurrence of secondary fracture around intramedullary nails used for trochanteric hip fractures: a systematic review of 13,568 patients. Injury 2012;43:706-11. [CrossRef]

22. Balm R, Hoornweg LL. Traumatic aortic ruptures. J Cardiovasc Surg (Torino) 2005;46:101-5.

\section{ORIJINAL ÇALIŞMA - ÖZET}

\section{İntertrokanterik femur kırıklarının tedavisinde entegre sefaloservikal vidalı intramedüller çivi: Kırık stabilitesine vida pozisyonunun etkisi \\ Dr. Gökhan Kaynak, Dr. Mehmet Can Ünlü, Dr. Mehmet Fatih Güven, Dr. Ozan Ali Erdal, Dr. Okan Tok, Dr. Hüseyin Botanlıoğlu, Dr. Önder Aydıngöz}

İstanbul Üniversitesi Cerrahpaşa Tıp Fakültesi, Ortopedi ve Tavmatoloji Anabilim Dalı, İstanbul

AMAÇ: Yaşlı popülasyondaki intertrokanterik femur (ITF) kırıklarının tedavisinde, redüksiyon kaybını önlemek, erken mobilite sağlamak ve bağımsız yaşamın restorasyonu için stabil kırık fiksasyonu çok önemlidir. Bu çalışmanın amacı, entegre iki sefaloservikal vida mekanizması içeren trokanterik antegrad intramedüller çivi (Intertan ${ }^{\circledR}$; Smith \& Nephew, Memphis, TN) kullanılarak cerrahi tedavi edilen stabil ve instabil iTF kırıklarının sonuçlarını ortaya koymak ve redüksiyon kaybı ile femur boynuna giden iki vidanın pozisyonu arasındaki ilişkiyi değerlendirmektir.

GEREÇ VE YÖNTEM: Çalışmada 2010 ve 201 I yılları arasında iTF kırığı olan ve Intertan ${ }^{\circledR}$ ile cerrahi tedavi edilen 57 hasta (22 erkek, 35 kadın) tüm plan deformiteleri ve redüksiyon kaybı açısından incelendi. Redüksiyon kaybını tarif etmek amacıyla iki indeks (frontal planda vida hiza indeksi [VHikoronal] ve lateral planda vida hiza indeksi [VHilateral]) belirlendi. Hastalar ayrıca Harris kalça skoru ve Barthel indeksine göre de değerlendirildi.

BULGULAR: Ortalama hasta yaşı 77. I, ortalama takip süresi 21.7 aydı. Tüm hastalarda tam kaynama elde edildi. Hiçbir hastada varus kollapsı ya da redüksiyon kaybı gözlenmedi. Takip süresi sonunda, ortalama Barthel indeksi 90.7 olarak bulunurken, ortalama Harris kalça skoru 83.7 olarak belirlendi.

TARTIŞMA: Femur baş/boyun fragmanının rotasyonel stabilitesini sağlamaya ve lineer intraoperatif kompresyona olanak tanıyan, entegre iki sefaloservikal vida mekanizması içeren trokanterik antegrad intramedüller çivi, redüksiyon kaybını önler ve femur başında geniş uygulama sahası mevcuttur. Mekanizmanın doğası, stabilitenin devamlılı̆ını sağlayarak erken yük verdirilmesine ve erken mobilizasyona olanak tanır. İntertrokanterik femur kırıklarının tedavisinde güvenli ve etkili bir tedavi seçeneğidir.

Anahtar sözcükler: Entegre sefaloservikal vida; intertrokanterik kırık; kalça kırı̆ı; sonuç; vida pozisyonu.

Ulus Travma Acil Cerrahi Derg 2018;24(3):268-273 doi: 10.5505/tjtes.2017.96933 